\title{
Precarious and Productive work in the digital economy
}

DOI:

10.1177/002795011724000110

\section{Document Version}

Accepted author manuscript

Link to publication record in Manchester Research Explorer

\section{Citation for published version (APA):}

Coyle, D. (2017). Precarious and Productive work in the digital economy. National Institute Economic Review, 240(1). https://doi.org/10.1177/002795011724000110

\section{Published in:}

National Institute Economic Review

\section{Citing this paper}

Please note that where the full-text provided on Manchester Research Explorer is the Author Accepted Manuscript or Proof version this may differ from the final Published version. If citing, it is advised that you check and use the publisher's definitive version.

\section{General rights}

Copyright and moral rights for the publications made accessible in the Research Explorer are retained by the authors and/or other copyright owners and it is a condition of accessing publications that users recognise and abide by the legal requirements associated with these rights.

\section{Takedown policy}

If you believe that this document breaches copyright please refer to the University of Manchester's Takedown Procedures [http://man.ac.uk/04Y6Bo] or contact uml.scholarlycommunications@manchester.ac.uk providing relevant details, so we can investigate your claim.

\section{OPEN ACCESS}


Precarious and productive work in the digital economy

Diane Coyle, University of Manchester

Digital platforms have the potential to create benefits for their suppliers or workers as well as their customers; yet there is a heated debate about the character of this work and whether the platforms should be more heavily regulated. Beyond the high-profile global platforms, the technology is contributing to changing patterns of work. Yet the existing framework of employment legislation and public policy more broadly - from minimum wages to benefits and pensions - is structured around the concept of 'the firm' as the agent of policy delivery. To reshape policies in order to protect the interests of people as workers as well as consumers, it is important to understand why digital innovators make the choices they do, and therefore how labour market policies can improve working conditions without constraining the productivity and consumer benefits enabled by digital business models.

JEL codes: J08, D20, O35

\section{INTRODUCTION}

Digital technologies are significantly affecting the way businesses and individuals organize production and work. As has always been the case, major technological change is disruptive. The effects of the digital economy on work are a particular focus of concern, and in this context there has been much debate on issues ranging from the potential loss of employment as a result of new artificial intelligence technologies to the pay and conditions of 'gig' work through digital platforms. ${ }^{1}$ This paper focuses on digital platforms, some of them high profile global businesses that have been particularly controversial as exemplars of the 'gig economy'. These platforms have become associated with contingent or 'gig' work, although such non-conventional forms of employment extend far beyond the digital sector. As the platforms have no business if they cannot attract suppliers or workers (because the value they create lies in the matching process between supplier and consumer), the work opportunities they create need to be more attractive than the outside options in the labour market. However, the emergence of the debate about contingent work in the context of the growth of the digital platforms offers both a need and an opportunity to re-evaluate the way the state delivers social and employment protection to individuals.

'Platform' is the term often applied to hybrid entities using digital technology as an interface between the users or consumers of a product or service and its suppliers. They share some of the features of: traditional businesses co-ordinating a supply chain; intermediaries or wholesalers connecting smaller suppliers to markets; networks connecting end-users to each other; and exchanges or market places where individual suppliers and buyers meet to trade. Different strands of economic research have been brought to bear on these platforms, including the pioneering work of Jean Tirole and others on two-sided markets, an older literature on networks, and recent work on market design. ${ }^{2}$

\footnotetext{
${ }^{1}$ For example, Arntz et al 2016; Hathawy \& Muro 2016

${ }^{2}$ They are sometimes called multi-sided platforms, two-sided markets, peer-to-peer platforms, networks - depending on the specific context. Key early research includes Jean-Charles Rochet and Jean Tirole,; Caillaud, Bernard and Jullien, Bruno, (2003; J.-C. Rochet and J. Tirole., 2006. Surveys can be found in Rysman, 2009, David S Evans, 2011, and Geoffrey Parker, Marshall van Alstyne and Sangeet Paul Choudary, 2016.
} 
There are longstanding examples of economic institutions or organisations that could be characterised as platforms. A traditional bazaar is one, acting as a known location for merchants and customers to meet and exchange. More recent examples include payments card networks enabling transactions between consumers and retailers; or operating systems co-ordinating the technical standards for programme developers and computer users. And some forms are new, such as 'sharing economy' peer-topeer platforms. It is surprisingly hard to pin down a definition of platforms, however, as they have characteristics of firms and of markets, involving both production and exchange; and they involve different kinds of co-ordinating mechanism - sometimes technical standards, sometimes exchange algorithms, sometimes social norms. In a sense, a platform is a business strategy as much as an organisation, and some firms operate both one and two-sided lines of business (such as Amazon as a retailer and Amazon Marketplace). There has been some debate, still unresolved, about whether platforms are best categorized by function or by business model. Kenny and Zysman (2015) argue for a functional approach, listing, for example, intermediation, bidding markets, service provision, and social/political organization. The definitional issues matter because, as Strowel and Vergote (2016) point out, a stable legal definition is necessary for effective regulation; they note: "Our view is that legal disruption is not an accident of the platform economy, it is a core feature." The ability of global platforms to occupy legal grey areas affects not only employment patterns and protections, the focus here, but also consumer protection and the reliability of the national tax base. These issues are not considered further in this paper but are of course of great public policy importance.

For all the regulatory concerns, however, platforms creat genuine economic value (as Strowel and Vergote acknowledge). They offer a way of addressing the fundamental problem of economic organization, how to co-ordinate the supply and demand (of millions of individuals in the case of consumer markets) in the absence of full information. Traditional markets co-ordinate using location, as in an old-fashioned marketplace, or time, as in financial market auctions. Platforms achieve improved coordination using technology. Participants do not need to be co-located, and while individual transactions happen very quickly, they do not all need to occur at the same time. There is thus also a dramatic reduction in search costs. The importance of information for the economy is well understood. Hayek presented the price system in a market economy as a decentralised mechanism for effective co-ordination when everyone has some unique information about their own preferences, or costs. ${ }^{3}$ But many economic transactions take place within firms, rather than in marketplaces, reflecting Coase's insight that sometimes the transactions costs involved in a market exchange would be higher due to asymmetries of information or an absence of clearly-defined property rights. He pointed out that changes in information technology (the telephone) and in management techniques could change the optimal size and organisation of a firm. ${ }^{4}$

It is not surprising then that the steep decline in the cost of exchanging information would alter transactions costs and therefore the kind of economic organisations that exist. The cost of information and communication technologies has been falling extremely rapidly for some time now, but some more recent innovations have opened the way for the growth of platforms as a model. In particular, access to ubiquitous fast broadband via wifi or $3 G / 4 G$ and the exponential growth of smartphone

\footnotetext{
${ }^{3}$ Hayek (1945)

${ }^{4}$ Coase (1937)
} 
ownership since 2008 means platforms that connect many individuals at any time are now viable. Technology is therefore an important element in the emergence of digital platforms. Another set of innovations from the discipline of 'market design', the strand of economics devising algorithms for matching heterogeneous demand and supply in a context of incomplete information, has been an important enabler of certain kinds of platforms, where the reduction in search costs is one of the key drivers of value. ${ }^{5} \mathrm{~A}$ number of other innovative enabling technologies have also helped platforms implement improved matching, including importantly digital means of payment and other financial innovations. The fact that so many enablers have been aligned lower transactions costs, lower search costs, and innovations in business models and complementary communications systems, software and services - helps explain why the platform phenomenon has been so sudden and striking. But it is worth emphasizing here the effects of digital technology on organizational structures because, as discussed further below, a good deal of public policy with regard to work and incomes is built around and delivered through the traditionally organized business firm. Digital platforms do not sit comfortably with this conventional mode of policy delivery.

\section{THE ECONOMICS OF DIGITAL PLATFORMS}

Digital platforms have proven particularly disruptive to incumbent businesses in certain sectors of the economy, prominently highly regulated sectors such as finance or taxis, where there is ample scope for regulatory arbitrage. Where they succeed and many fail - it is because they deliver value to their users, on both the consumer side and the supplier side. Even where side-stepping regulation (including increasing competition by routing round regulatory barriers to entry) is part of the story, the observed rapid growth in the success stories is explained by the fact that platforms enable interactions or exchanges that make all participants better off by more, the more people take part on the other side of the platform; there are indirect network effects. The platform benefits buyers by assembling sellers, and sellers by assembling buyers. In the context of economies with increasingly varied types of goods and services on offer, and increasing scope for customisation, the consumer value of improved matching technologies has increased too. Finally, without the platform, transactions costs would make it impossible for the resulting exchanges to take place. An early vintage new economy example is Ebay, which makes it possible to sell or purchase niche products because it assembles large enough numbers of buyers and sellers. And a new digital example is Airbnb, which is bringing new supplies of short-term accommodation to market because so many travellers use the site, and this happens because it has a large number of properties listed. Some platforms (such as social media networks) are also characterised by direct network effects.

The indirect network effects make it essential for platforms to get the right balance between providers and consumers on the platform, which depends on how they set the price on each side. In their classic early paper in this literature, Rochet and Tirole (2006) make this issue the key to defining a two-sided market: "The price structure matters, and the platform must design it so as to bring both sides on board." There is in general one side of the platforms whose participants cross-subsidize those on the other side. The subsidy will go to the side whose demand is more sensitive to price -

\footnotetext{
${ }^{5}$ Roth (2015)
} 
typically consumers - and the two prices will be linked depending on how much benefit each side gains from the presence of the other. If the platform gets it wrong, and sets the price too high on one side, so there are few of them participating, the price participants on the other side are willing to pay to access the platform will be lower. Discouraging participation on either side by getting the price wrong can lead to a downward spiral. Conversely, a positive feedback loop can lead to rapid growth in transaction volumes when a platform manages to attract consumers, which attracts more suppliers, which attracts more consumers, and so on. New platforms therefore need to reach a critical mass beyond which the positive feedback operates. When this point is reached, the platform's growth can be rapid.

The expansion of the so-called sharing economy has been a notable recent phenomenon. Big platforms in this sector - such as Uber and Airbnb - have prompted a great deal of commentary about their business model and practices, and calls (often from incumbents) for specific regulation to constrain their business practices. In the UK the Office for National Statistics estimated there were 50 sharing economy platforms in 2015, up from 10 in $2010 .{ }^{6}$ The distinction between sharing economy platforms and other types of platform is not a sharp one, and is arguably mainly marketing. But sharing economy platforms can be characterised as aiming to match many suppliers and many consumers (or in other words they are peer-to-peer), where the suppliers are able to use more intensively through the platform an asset they own, such as an apartment, car, tool or skill. The technology - the combination of matching algorithm, pervasive internet connectivity and digital device - make it feasible to rent out the asset when it is not in use because transactions and search costs have been lowered so dramatically. These basic economic characteristics mean sharing economy platforms are viable when there is sufficient heterogeneity in demand and when there are no large economies of scale in production.

CHART: Growth in number of sharing economy businesses, UK. Source ONS [Fig 1.xls]

30 Number of businesses

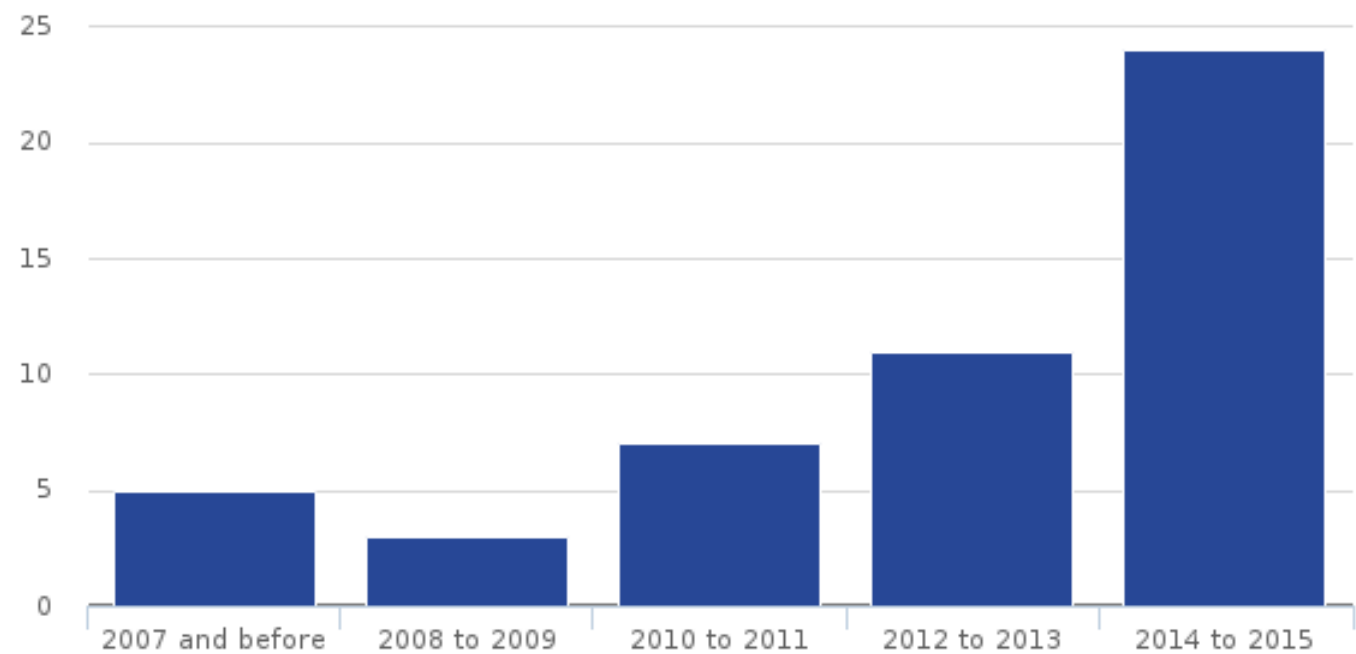

${ }^{6}$ ONS 2016. It is worth noting that in the UK, Uber does not operate as a 'sharing economy' platform but rather as a licensed private hire company. 
The realisation of the value from the direct and indirect network externalities - the increased number of transactions, the better matching of (varied) supply and demand and the reduced transactions costs on the platform - means there is scope in principle for all parties to benefit. The social welfare gains from platforms are potentially sizable. ${ }^{7}$ The platform's margin will depend on competition; in many sectors (such as restaurant bookings) competing platforms offer the same service; but there are others dominated by a single large platform. Competition authorities are currently struggling with the challenges these markets pose in terms of market definition and analysing the cross-subsidy between the sides. ${ }^{8}$ However, public debate about these platforms has focused not on consumer gains and competition analysis (even where the platforms are increasing competition in regulated markets such as taxi markets), but rather on possible demand side externalities (such as the negative impact of rowdy short-term travellers on residential neighbourhoods) and on the conditions of employment for those working through digital platforms.

\section{DIGITAL PLATFORMS AND WORK}

One of the challenges in the debate about the consequences of digital platforms, and particularly those often described as the 'gig economy' is a lack of data - a problem specifically highlighted in a recent high-profile US National Academies report Information Technology and the US Workforce (2017). What's more, arguments and anecdotes are often carried over from one country or region to another when workers' outside options in the labour market differ greatly. Controversy has probably been greatest in the United States, where the minimum wage is lower than in many European countries, where job security and working conditions in alternative jobs are poor, and where there is less provision of public services including, importantly, health coverage. Similarly, there are big differences in employment and unemployment rates between OECD countries. To the extent that low pay or bad conditions in any one sector or business reflect the absence of attractive outside options, the focus for policy intervention should be on the broader state of the labour market.

It is also important to distinguish between different types of platform, such as those for professional workers with high human capital or those providing highly differentiated services (such as Thumbtack or Etsy) and those for more commoditized work such as deliveries, cleaning or gardening. In the former case the individual worker will have more control over their hours and terms of work, will rely more on individual reputation and rating, and will be likely to work via several platforms or off the platform as well. In addition, some platform models incorporate another category of work, namely intermediaries such as delivery drivers and couriers or warehouse staff. These are the subject of the greatest policy concern and controversy about their pay and working conditions. The economic literature on platforms does not take into account the distribution mechanisms; for digitised services or products such as consultancy or video games this is a reasonable starting point (although even in those cases the assumption of costless and frictionless distribution ignores the costs of the underlying physical network); but it is an important missing element in the case of the controversial platforms reliant on human couriers or drivers.

\footnotetext{
${ }^{7}$ Benjafaar et al (2015)

${ }^{8}$ Evans \& Schmalansee 2014
} 
The current legal cases in the United States, United Kingdom and elsewhere hinge precisely on questions such as the degree of control the individual involved in the distribution network has over hours, the way the task is performed, whether they must use platform branding and so on. ${ }^{9}$ What's more, the focus on contingent work for digital platforms has widened to encompass similarly contingent work in conventional businesses making use of large numbers of individuals to fulfil jobs - for example, plumbers, couriers, cleaners, taxi drivers. Legal rulings concerning digital platforms will have consequences for non-digital businesses implementing similar practices.

All in all, platform models clearly pose or intensify a challenge to the existing framework of employee and consumer protection, shaped around traditional business organisations. But it is perverse to argue that the best policy response is to make the digital platform models unviable, losing the benefits they deliver to both producers and consumers, in order to ensure they conform to the existing regulatory and policy framework. The European Commission has recently cautioned against over-rigid application of regulations to what it termed the 'collaborative economy' platforms, while recognising that taxation and regulation will need to adapt to the new models. ${ }^{10}$ The focus on seeing work via the platforms through the lens of 'jobs' overlooks other dimensions too. Millions of people are able to use their assets (including human capital) more efficiently to make some additional income, often with control over their hours and locations. The platforms provide an on-ramp to the formal labour market for people who might have been out of work for some time - such as mothers who have been caring for children, or the long-term unemployed. ${ }^{11}$ What's more, the fact that non-digital businesses also make use of contingent forms of work makes it timely to step back and reconsider how public policy goals are best delivered in the round, given the broad changes in business and employment.

\section{Scale}

The first question to consider is how widespread are the various forms of contingent work. Many of the statistics of interest when it comes to analysing the employment effects of digital platforms are captured within existing statistics, but cannot be uncovered on a standalone basis, partly because researchers and commentators use varying definitions, and partly because the activities of the platforms cross several of the standard industrial sectors. The ONS has work under way to extend its survey coverage to some of the big 'sharing economy' platforms and add some questions to existing surveys. ${ }^{12}$ It is meanwhile natural to turn to various labour market statistics for insight, but these tell a complex story. Agency work has increased by almost a third since 2011. The number of zero hours contracts reported by individuals through the Labour Force Survey has leapt, more than quadrupling over the same period, to reach a similar scale to agency work (905,000 by the end of 2016). In total $2.8 \%$ of those in employment report they are on zero hours contracts, and a similar proportion describe themselves as agency workers. These categories are still small compared to self-employment, which has also been increasing (since 2000), and has grown faster than employment since the financial crisis. It now accounts for just under $15 \%$

\footnotetext{
${ }^{9}$ Sundararajan (2016) Chapters 7-8, See also https://www.thumbtack.com/blog/beyond-thegig-economy/

${ }_{10}$ EU Commission (2016)

${ }^{11}$ Fraiberger and Sundararajan (2015; Chassany, Financial Times 3 March 2016.

12 'ONS (2016)
} 
of all employment, and for a quarter of the growth in total employment since $2008 .{ }^{13}$ The self-employment category is heterogeneous, including people earning a wide range of incomes. About three quarters work in services, spread across a wide range of activities. ${ }^{14}$ The proportion in finance and business services has risen significantly. Since 2008, there has been a roughly even split between increases in part time and full time self employment. Few of the self-employed report they would rather be in employment.

However, all of these categories will include many people other than those working for or through digital platforms (although it is reasonable to assume that digital technologies in general have made it much easier to be self employed in some occupations, particularly among professional and creative occupations). Conversely, there are people earning some income from platforms whose activity and earnings are unlikely to be captured at all in the statistics. Some of the activity may be small in scale, such as occasional letting of accommodation through Airbnb or selling hobby handicrafts on Etsy. Some might be larger in scale but not thought of by the individual in the same terms as the questions on employment surveys. For instance, someone doing small-scale trading of books or clothes using eBay or Amazon Marketplace might not fit her activity into any of the categories included in the Labour Force Survey questionnaire, which poses jobs, self-employment, and working for own or family business as mutually exclusive and exhaustive. Similarly, while driving for Uber - which operates as a licenced private hire company in the UK - will be recorded just as effectively in the statistics as other minicab drivers, people who are renting accommodation on a small scale on Airbnb will not think of it as 'work', even though it clearly involves work.

Questions on zero hours contracts, agency working and home working are included in the Labour Force Survey but in a context that indicates these are sub-categories of employment or self-employment. ${ }^{15}$ It is not clear that someone in fact working under one or more zero hours contracts, at the casualised end of the market, would think of themselves as in employment. Business surveys provide additional statistics on the number of zero hours contracts; this exceeds the number of individuals as people will sign up for more than one. ${ }^{16}$ There has been growth in the use of zero-hours contracts, some of it likely due to increased awareness. The most contingent kinds of work in the digital sector, including 'second jobs', paying hobbies and so on, are less likely to be captured in any of the statistics.

INSERT CHART -SELF-EMPLOYMENT SINCE 1999 INSERT CHART ON ZERO HOURS CONTRACTS

[Figs 2,3 xls files]

13

https://www.ons.gov.uk/employmentandlabourmarket/peopleinwork/employmentandemployee types/articles/trendsinselfemploymentintheuk/2001to2015

https://www.ons.gov.uk/employmentandlabourmarket/peopleinwork/employmentandemployee types/datasets/selfemploymentjobsbyindustryjobs04

${ }_{16}^{15}$ Labour Force Survey User Guide Volume 2, 2015.

https://www.ons.gov.uk/employmentandlabourmarket/peopleinwork/earningsandworkinghours /articles/contractsthatdonotguaranteeaminimumnumberofhours/march2016 

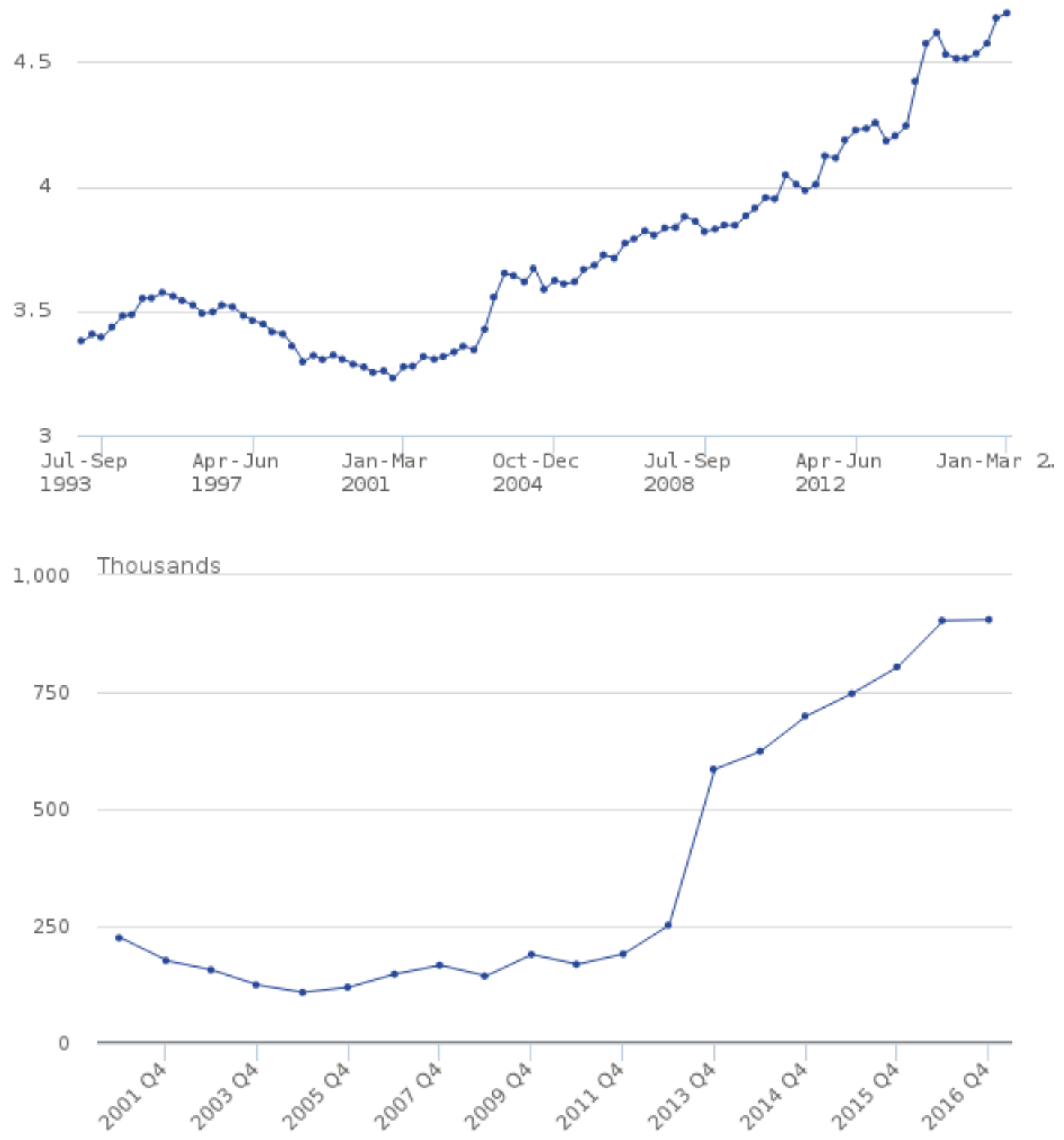

There is some additional survey evidence on the scale of activity in the sharing economy. Nesta has estimated that a quarter of the UK population has engaged in a sharing economy activity. ${ }^{17}$ Figures provided by members of the trade body SEUK suggested more than a million people were signed up to their websites as providers (although it is not possible to know the overlap between the platforms i.e. how many people who use one also use others), This is equivalent to about $3 \%$ of the workforce, although many or most of them probably do not regard this as employment in any conventional sense. ${ }^{18}$ An indication of scale is also provided by consumer expenditure data: ONS data indicate that in February 2017, the proportion of retail sales (excluding fuel) purchased online had climbed to $15.3 \%$, more than a fifth higher than in February 2016. While only a portion of this will be purchases

\footnotetext{
${ }^{17}$ Stokes et al, 2014.

${ }^{18}$ Coyle 2016.
} 
through digital platforms - for example, it includes online grocery shopping from supermarkets - there is little doubt from these figures that digital is changing consumer behaviour significantly, and therefore that consumer-facing businesses will be changing their organization and employment patterns.

It seems a safe conclusion that kinds of working patterns associated with digital platforms have been increasing, albeit for other reasons too. The available statistics indicate that apart from self-employment (which includes a wide range of activities), the scale is relatively small. There are, though, types of contingent work not captured in existing statistics, and sometimes for the good reason that that the people engaged in these activities may not think of it as work at all.

\section{Role of policies in changing work patterns}

There are other drivers of these trends in patterns of work apart from the growth of the digital economy. One factor may be the relatively weak state of the labour market, post-crisis; while the employment rate is at a record, real earnings growth has been slow, especially for unskilled workers. On the other hand, the upward trend in selfemployment dates from 2000. Increased awareness and reporting might account for part of the increase in zero hours contracts.

A range of policy and regulatory changes will also have affected the incentives for some employers and employees to seek alternatives to conventional employment contracts. Much attention has focused on the cost of employment, including the rising minimum wage (National Living Wage, NLW) and the apprenticeship levy, although the preliminary evidence to date is that the NLW has had little effect on employment and hours. ${ }^{19}$ Recently, as a result of the announcement and rapid withdrawal of the plan to equalise national insurance contributions for the self-employed, the focus has been on the differential tax treatment of the two modes. The IFS has noted the large tax advantage to the self-employed and owner-managers. ${ }^{20}$ They (and others) argued that the differential access to benefits for the self-employed is not commensurate with the large tax advantage of this status. However, the failure to link a tax increase on the self-employed and owner managers (in the form of higher National Insurance contributions) to any improvement at all in access to benefits backfired politically; the proposal was withdrawn. Equalising tax treatment would anyway tackle only part of the regulatory incentive against employment. A result of the difference in access to benefits for the self-employed and employed is that employers incur costs in delivering and administering a range of benefits to the latter, such as parental leave and sick pay. The administrative burden - the 'red tape' about which businesses so often complain - has increased incrementally but steadily over time. All but the very smallest employers now need to ensure their staff are enrolled in a pension scheme, and must now provide training in the specific form of the apprenticeship scheme to recoup the levy. Employers are now required to police immigration policy, a cumbersome process, with failure to do it correctly subject to significant penalties. The government in sum uses employers as policy administrators. These indirect costs which have increased over time and mark another cost differentiator between employment and self-employment (or the use of agency staff). Policy officials (who are administrators) and analysts largely do not appreciate that these administrative costs are high, and so shift policy

\footnotetext{
${ }^{19}$ Low Pay Commission 2016.

${ }^{20}$ Adam et al, February 2017.
} 
implementation costs from the state to employers without taking due account of the likely consequences for employment practices.

Other public policies have contributed to the growth of agency work and zero hours contracts. Spending cuts in social care and other services have driven employers such as care homes and local authorities to bear down heavily on costs, mainly labour costs in these sectors. People in health and social work form the second biggest category of those reporting they are working on zero hours contracts (accommodation and food is first, transport and the arts third; these three make up over half the total).

Finally, when it comes to the digital platforms specifically, regulatory arbitrage is one possible explanation for the prominence of these platforms in sectors such as accommodation, transport and finance. In other words, there is more scope for platforms to enter markets where incumbents are highly regulated, which poses a significant barrier to entry but also adds to their costs and lack of flexibility in service provision. Of course, the perception that the regulatory playing field is uneven helps explain some legal challenges against platforms such as Airbnb and Uber, although this does not directly concern the employment status of suppliers to the platform.

\section{Platforms as a business model choice}

However, regulatory arbitrage is certainly not the only rationale for operating as a platform. To think about the choice of a platform as business model, compare the transactions costs in the case of a platform as opposed to a traditional firm which contracts with suppliers and sells its product to consumers, in a conventional supply chain. (There is of course also a large literature about firms' choice between vertical integration and contracts with external suppliers.) The advantage of a platform lies in its ability to reduce consumers' or buyers' search costs and to reduce shared transaction costs between the various sides, to a greater extent thanks to direct matching between suppliers and customers. ${ }^{21}$ For example, Amazon as an online retailer has the advantage of large economies of scale and its significant investments in logistics; Amazon as a platform through Marketplace added indirect network effects. Google started as a one-sided search business and has steadily added more 'sides' beginning with AdWord and AdSense, but also social media, internet telephony and so on. The business landscape is in flux in many countries as traditional businesses try to capture the advantages of two-sided or multi-sided operation, and existing platforms increase the number of 'sides' to increase the network effects they can capture, and share with their users on all sides. This flux is often labelled 'convergence'. As Hagiu (2007) puts it: "Indirect network effects generate powerful demand-side economies of scale and scope, which, combined with technology, render industry barriers quite porous."

Hagiu and Wright (2016) argue that the decision between traditional vertically integrated organization of the firm and platform organization reflects the allocation of control over the transactions and the extent of moral hazard affecting the firm and its employees or contractors. They see the control (over pricing, bundling, marketing, delivery and so on) by individual agents as a key distinction between a platform and other models of business organisation. The choice of model is not always obvious. For example, a traditional consultancy employs professionals directly whereas a platform matches independent consultants setting their own fees to clients. The

\footnotetext{
${ }^{21}$ Summarised by Hagiu (2007); Hagiu and Wright (2015)
} 
quality of the individual consultants' work is hard to monitor. "A key tradeoff emerges between the need to coordinate decisions such as marketing that generate spillovers across professionals (best achieved by a vertically integrated firm) and the need to both motivate unobservable effort by professionals (best achieved by a multisided platform)." There are also questions about the future evolution of platforms. Is it just a matter of time before platforms drive out incumbents with traditional business models, or before the incumbents switch organizational model? Might some platforms indeed evolve toward becoming traditional supply chain intermediaries with users on each side not having direct contact with each other? Certainly, some incumbent industries fear the former will occur, and as noted are calling for regulatory protection. Alternatively some are acquiring platforms. For example, recently Accor purchased the luxury accommodation platform One Fine Stay and Enterprise car rentals purchased City Car Club.

In other words, where the scope for indirect network effects makes a digital platform a commercially attractive (and social welfare-enhancing) choice, the platform will need to create incentives for suppliers to join the platform and provide a sufficiently high quality service or product. Otherwise, there will not be enough consumers on the other side, and the platform will collapse into a downward spiral. This is the case even with goods or services that are in principle easier to monitor than consultancy, because in practice as soon as a platform reaches a certain scale, it cannot feasibly enforce its own quality control over thousands of individual suppliers. While most digital platforms use ratings systems to allow customers to give feedback on individual suppliers, the evidence is that they do not work well, as customers tend to give only high ratings - or none. ${ }^{22}$ Therefore the platforms need to ensure they provide the incentives for suppliers to do a good job. Otherwise, they will risk entering a spiral of decline, losing customers, becoming less attractive to suppliers, and so on. To put it another way, some of the social welfare gain from indirect network effects internalized by the platforms will have to be shared with both sides of the platform, with consumers and suppliers or workers. Without a reputation for excellent service, the platform has no business. Lacking other mechanisms over individual suppliers' or workers' behavior - those available to employers - the platforms will need to provide at least minimally attractive pay and conditions. After all, in a labour market like the UK's where the employment rate is at a near-record level, individuals do have outside options. Uber drivers, for example, could work for other minicab companies; their choice is not forced. This does, however, flag a potential policy concern, which is the theoretical scope for platforms to become monopsony buyers in the labour market. The discussion of their market dominance in the literature focuses on the product market side. However, it would also be possible for them to become dominant in certain geographic labour markets.

\section{DISCUSSION: POLICY CHALLENGES}

The growth of digital platforms and the broader growth of self-employment and contingent work - for a range of reasons including the fact that digital technology is making these work patterns more feasible - nevertheless raises questions for policy makers. The urgency of the issues is evident, as the commissioning of the forthcoming Taylor Review in the UK indicates. ${ }^{23}$ Its work has involved scrutinizing

\footnotetext{
${ }^{22}$ Dellarocas et all (2006), Boudreau and Hagiu (2007),

${ }^{23} \mathrm{https}$ ://www.gov.uk/government/groups/employment-practices-in-the-modern-economy
} 
precisely the issues and data highlighted here. Some agency, zero hours contract and self-employed workers are vulnerable, lacking the protections or mechanisms to attain reasonable working conditions and earnings; this group overlaps with those working for some of the digital platforms. The platforms raise a separate question, though, namely the allocation of the significant value they are creating through the reduction in search and transactions costs and capture of network effects: at present it appears that the value is largely captured by investors and consumers rather than workers and tax authorities, although this is impressionistic, and the allocation of the increased social welfare remains an important empirical question.

However, when it comes to employment patterns, the growth of the digital platforms has put a spotlight on a broader, fundamental policy question. If more than a fifth of the workforce is now working in contingent, non-traditional employment, and the proportion seems to be rising rapidly, it is becoming decreasingly sensible or feasible to deliver social protections and other policies (such as training or immigration control) through conventional employers. The rapid reversal of the March 2017 Budget proposal to make the tax treatment of the self-employed and owner managers more like that of the employed highlights the risk of considering some parts of the social contract in isolation from others. This is an opportunity to think in the round not just about equalizing the tax treatment of different categories but also the whole relationship between individual, firm and state. Although the March 2017 proposal to equalize $\mathrm{NI}$ treatment looked to many economists like the sensible reduction of a tax distortion, from the perspective of individuals the structure of the overall employment deal looks very uneven, as the table indicates.

\begin{tabular}{|l|c|c|c|}
\hline \multicolumn{1}{|c|}{ Rights: } & Employee & 'Worker' & Self-employed \\
\hline Unfair dismissal & $\checkmark$ & $x$ & $x$ \\
\hline Parental leave & $\checkmark$ & $x$ & $x$ \\
\hline Sick pay & $\checkmark$ & $\checkmark$ & $x$ \\
\hline Minimum wage & $\checkmark$ & $\checkmark$ & $x$ \\
\hline Working time limits & $\checkmark$ & $\checkmark$ & $(\checkmark)$ \\
\hline $\begin{array}{l}\text { Discrimination } \\
\text { protection }\end{array}$ & $\checkmark$ & $\checkmark$ & $\checkmark$ \\
\hline $\begin{array}{l}\text { Health \& safety } \\
\text { protection }\end{array}$ & $\checkmark$ & $\checkmark$ & $\checkmark$ \\
\hline Benefits & $\checkmark$ & $\checkmark$ & $\begin{array}{c}\checkmark \text { most-complex } \\
\text { to apply }\end{array}$ \\
\hline State pension & $\checkmark$ & & $\begin{array}{c}2016, \text { if born } \\
\text { after 6/4/51 \& } \\
\text { have paid 35 } \\
\text { years of NI } \\
\text { contributions }\end{array}$ \\
\hline
\end{tabular}

HMRC, DWP, Resolution Foundation ${ }^{24}$

It is also important, while protecting individual rights to decent working conditions and pay, and avoiding a race to the bottom, to be alert to the risk of regulatory capture by incumbents, businesses, unions and employees, and self-employed incumbents alike. A heavy burden of regulation on certain sectors is both a cost to those business and self-employed workers, and an entry barrier. Certain forms of deregulation would be

${ }^{24} \mathrm{http}: / /$ www.resolutionfoundation.org/app/uploads/2017/02/Self-employment-presentation.pdf 
likely to increase consumer and social welfare. At the same time it is clearly desirable for some kinds of 'gig' workers - at the low skill and earnings end of the spectrum to be able to combine and exercise collective power to improve their conditions.

At present these trade-offs and regulatory considerations are being played out in the courts, which are interpreting legislation passed for the pre-digital platform era. Simply regulating digital platforms to make them act like conventional businesses or prevent new platforms emerging - will lead to a loss of social welfare, including for those individuals on the supplier side of the platforms. It is no surprise that the substantial decline in the costs of communication and information processing are continuing to change the way businesses are organized and the way people work. This change in the structure of work has been on the cards for 20 years, since it became clear that ICTs were a general purpose technology. ${ }^{25}$ The time has come for legislators to ask whether the conventional firm and the conventional employment contract are suitable vehicles for policy delivery, or whether instead a 'digital' social contract is needed. This could be conceived as having no intermediary institution between the individual and the government, but rather a digitized relationship embodying a Beveridge-style insurance approach; or as involving alternative intermediaries. But this discussion is one for substantial political debate, just like the original creation of the post-war welfare state.

\section{REFERENCES}

Adam, Stuart, H Miller \& T Pope, Tax, Legal Form and the Gig Economy, IFS February 2017, https://www.ifs.org.uk/publications/8872

Arntz, Melanie, T Gregory, U Zierahn, The Risk of Automation for Jobs in OECD Countries, OECD Working Paper May 2016. http://www.oecd-ilibrary.org/socialissues-migration-health/the-risk-of-automation-for-jobs-in-oecdcountries 5jlz9h56dvq7-en

Benjaafar, Saif, Guangwen Kong, Xiang Li, Costas Courcoubetis, 'Peer-to-Peer Product Sharing: Implications for Ownership, Usage and Social Welfare in the Sharing Economy' (2015) http://dx.doi.org/10.2139/ssrn.2669823

Boudreau, Kevin J., and Andrei Hagiu. 'Platform Rules: Multisided Platforms as Regulators', In Platforms, Markets and Innovation, edited by Annabelle Gawer. Cheltenham, UK: Edward Elgar Publishing, 2009.

Caillaud, Bernard and Jullien, Bruno, 'Chicken \& Egg: Competition among Intermediation Service Providers,' RAND Journal of Economics, (2003) 34, issue 2, p. 309-28.

Coase, Ronald H, 'The Nature of the Firm', Economica, New Series, Vol. 4, No. 16. (Nov., 1937), pp. 386-405.

Chassany, Anne-Sylvaine, 'Uber: a route out of the French banlieue,' Financial Times 3 March 2016.

Committee on Information Technology, Automation, and the U.S. Workforce; Computer Science and Telecommunications Board; Division on Engineering and Physical Sciences; National Academies of Sciences, Engineering, and Medicine, Information Technology and the U.S. Workforce: Where Are We and Where Do We Go from Here?, March 2017.

Coyle, Diane, The Weightless World, Capstone 1997.

\footnotetext{
${ }^{25}$ Coyle 1997.
} 
Coyle, Diane, The Sharing Economy in the UK: a report for SEUK, Enlightenment Economics, January 2016.

Coyle, Diane, 'Making the Most of Platforms: A Policy Research Agenda', Toulouse School of Economics jean Jacques Laffont Digital Chair Working Paper, October 2016.

Dellarocas, Chrysanthos and Dini, Federico and Spagnolo, Giancarlo, 'Designing Reputation (Feedback) Mechanisms.' Handbook Of Procurement, Nicola Dimitri, Gustavo Piga, Giancarlo Spagnolo, eds., Cambridge University Press, 2006.

European Commission, A European Agenda for the Collaborative Economy, COM2016 356 (Final), http://ec.europa.eu/growth/single-

market/strategy/collaborative-economy/index_en.htm

Evans, David S, Platform Economics: Essays on Multi-Sided Markets, Competition Policy International, 2011

Evans, David S. and Richard Schmalensee 'Antitrust Analysis Of Multi-Sided Platform Businesses', in Roger Blair And Daniel Sokol, Eds., Oxford Handbook On International Antitrust Economics, Oxford University Press (2014).

Fraiberger, Samuel P. and Sundararajan, Arun, 'Peer-to-Peer Rental Markets in the Sharing Economy', (October 6, 2015). NYU Stern School of Business Research Paper.

Gawer, Annabelle, 'Technological platforms: Toward an integrative framework,' Research Policy, Volume 43, Issue 7, Sept 2014, Pages 1239-1249

Hayek, Friedrich A. "The Use of Knowledge in Society." American Economic Review. XXXV, No. 4. pp. 519-30. American Economic Association. 1945

Hagiu, A., 'Two-Sided Platforms: Product Variety and Pricing Structures.' Journal of Economics \& Management Strategy, 18: 1011-1043. doi: 10.1111/j.1530-

9134.2009.00236.x

Hagiu, Andrei. "Merchant or Two-Sided Platform?" Review of Network Economics 6, no. 2 (June 2007): 115-133.

Hagiu, Andrei, and Julian Wright. "Multi-Sided Platforms." International Journal of Industrial Organization 43 (November 2015): 162-174.

Hathaway, lan and Mark Muro,'Tracking the Gig Economy', Brookings Institute, October 2016. https://www. brookings.edu/research/tracking-the-gig-economy-newnumbers/

Kenny, Martin \& John Zysman, 'Choosing a Future in the Platform Economy: The Implications and Consequences of Digital Platforms', Kaufman Foundation

Discussion paper, June 2015. http://www.brie.berkeley.edu/wpcontent/uploads/2015/02/PlatformEconomy2DistributeJune21.pdf

Low Pay Commission, National Minimum Wage Report, Autumn 2016, https://www.gov.uk/government/uploads/system/uploads/attachment_data/file/57563 4/10583-LPC-National_Living_Wage_WEB.pdf

Office for National Statistics, 'The Feasibility of Measuring the Sharing Economy', April 2016,

https://www.ons.gov.uk/economy/economicoutputandproductivity/output/articles/thefe asibilityofmeasuringthesharingeconomy/2016-04-05

Geoffrey Parker, Marshall van Alstyne and Sangeet Paul Choudary, Platform

Revolution, Norton (2016).

Rochet, Jean-Charles, Jean-Charles and Jean Tirole, 'Platform Competition in Twosided Markets,' Journal of the European Economic Association, 2003, pp. 990-1029. J.-C. Rochet and J. Tirole. 'Two-sided markets: A progress report.' The RAND Journal of Economics, 37(3):645\{667, 2006.

Roth, Alvin, Who Gets What And Why? By, William Collins, 2015. 
Rysman, Marc, 'The Economics of Two-Sided Markets.' Journal of Economic Perspectives, (2009) 23(3): 125-43

Stokes, Kathleen, Emma Clarence, Lauren Anderson, and April Rinne. Making Sense of the UK Collaborative Economy. London: NESTA, 2014.

Strowel, Alain \& Wouter Vergote, Digital Platforms: To Regulate or Not To Regulate? Message to Regulators: Fix the Economics First, Then Focus on the Right Regulation, July 2016

http://ec.europa.eu/information_society/newsroom/image/document/2016-

7/uclouvain et universit_saint_louis 14044.pdf,.

Sundararajan, Arun, The Sharing Economy, MIT Press, 2016. 